\title{
Health needs of refugees: port of arrival versus permanent camp settings
}

Monica Matsumoto, ${ }^{1}$ Gabrielle Wimer ${ }^{2}$ and Aisha Sethi ${ }^{3}$

${ }^{1}$ Pritzker School of Medicine, Biological Sciences Division, University of Chicago, Chicago, United States of America. ${ }^{2}$ University of Chicago, Chicago, United States of America. ${ }^{3}$ Department of Dermatology, Yale University, New Haven, United States of America. (Correspondence to: Monica Matsumo to:mmmatsumoto3@gmail.com).

\begin{abstract}
Background: The world's refugee population has surpassed 21 million, the large majority of which resides in developing countries. Refugees have relatively high rates of healthcare utilization for management of both long-term needs, such as diabetes, and acute conditions, such as scabies.

Aims: Using interviews of stakeholders in disparate healthcare settings, we aimed to elucidate both common themes and areas of difference that should be recognized and addressed as the refugee crisis continues.

Methods: This qualitative interview study compared and contrasted two settings for healthcare provision for refugees: the permanent setting of Za'atari, a camp in Jordan, versus the transitory arrival location of Lampedusa, Italy.

Results: We presented data from 12 semi-structured interviews with experts in refugee health care that have experience in these two locations. We focused on issues of disease burden and health screening, organizational structures and services, cultural competency, and international response.

Conclusions: We compiled recommendations to improve health care for refugees include recognizing differing health needs of refugees in Za'atari and Lampedusa, training providers in culturally-competent care, screening for and treating psychiatric disorders, and prioritizing agency coordination, documentation, and advocacy.

Keywords: refugee health, education, non-governmental organizations, international health policy, cultural competency

Citation: Matsumoto M; Wimer G; Sethi A. Health needs of refugees: port of arrival versus permanent camp settings. East Mediterr Health J.

2019;25(5):306-314 https://doi.org/10.26719/emhj.18.041

Received: 22/11/16; accepted: 22/10/17

Copyright ( ) World Health Organization (WHO) 2019. Some rights reserved. This work is available under the CC BY-NC-SA 3.0 IGO license (https:// creativecommons.org/licenses/by-nc-sa/3.o/igo)
\end{abstract}

\section{Introduction}

The number of refugees worldwide reached over 21 million at the end of 2015 (1). Much of the recent displacement stems from political turmoil throughout the Middle East and North Africa. Many of these conflicts have evolved into humanitarian crises as fleeing civilians attempt to find safety. In 2015, over 1 million arrived in Europe by sea via Spain, Italy, or Greece, with over 3700 reported dead or missing (2).

In January 2016, over 5200 refugees arrived in Italy-a 50 percent increase over January $2015(2,3)$. Twentyone percent of refugees who arrived in 2015 landed in Lampedusa, Italy, a small island off the coast of Libya, on their way to mainland Europe (4). As a transitory location, Lampedusa serves short-term health needs of refugees, funded primarily by the Italian government. In contrast, Za'atari camp in Jordan houses 80000 Syrian refugees, many of whom have lived there for years due to the protracted conflict (5). Most of the estimated 4.3 million Syrian refugees live in neighbouring countries (Egypt, Iraq, Jordan, Lebanon, Turkey), and as the largest refugee camp for Syrians, Za'atari has an established healthcare system and data collection mechanisms. We believed that a comparison between Za'atari and Lampedusa would elucidate important lessons learned by stakeholders providing care to refugees and would allow us to create more generalizable and actionable policy recommendations regarding the refugee crisis.

Refugees are at risk for a variety of health problems because of travel through unsafe, unsanitary, and poorly resourced settings, exposing them to physical and psychological dangers. Even after reaching a border, refugees face continued challenges as they integrate into new communities, adapt to altered lifestyles, access healthcare, and deal with the effects of trauma. These influxes can strain resources of local communities, which are often assisted by nongovernmental organizations (NGOs), governments, and agencies like the World Health Organization (WHO) to provide basic health services (6).

As the number of refugees grows and outpaces available international funding, it becomes increasingly important to identify major gaps in healthcare, eliminate wasteful duplication, and prioritize areas of greatest need. We identify common trends across agencies and initiatives providing healthcare to refugees, including structural pitfalls and emerging problems. We devote much-needed attention to bringing together diverse experiences of healthcare providers in order to identify common themes and ideas for developing new programmes with the greatest amount of beneficence, justice, and efficacy. 


\section{Methods}

Lampedusa, Italy and Za'atari camp in Jordan were chosen as representative settings of a transitory arrival centre and a permanent camp setting, respectively. Lampedusa was chosen because of Italy's history of receiving refugees and Za'atari because it is the largest camp for Syrian refugees $(7,8)$. We then conducted a literature review of scholarly articles on Pubmed, as well as news sources and grey literature (technical reports by NGOs and UN agencies) of healthcare provision in these two settings from the past five years. The results informed the creation of a questionnaire (Supplement 1) for semi-structured interviews, conducted between January and March 2016, with individuals working with refugees in either Jordan or Italy. This interview format was chosen to minimize the time demands placed on interviewees, while still allowing for the emergence of new themes. The interviewees were selected based on author AS's contacts having worked in refugee response in Lampedsua and Za'atari, as well as individuals that were identified during the literature review. The interviewees were ultimately chosen to represent a cross-section of the different organizations involved in refugee health response: NGOs, national governments, and international organizations. The questionnaire and project received IRB approval from the University of Chicago's Biological Sciences Division Institutional Review Board.

Individuals were contacted via email addresses obtained either through publicly-available sources or private contacts. An initial email - and if necessary, one follow-up email - was sent requesting a Skype interview about his/her experience working with refugees in either Jordan or Italy, with a specific focus on healthrelated issues. The interviewee received the questions beforehand, and verbal consent was obtained prior to beginning the interview. Of the 17 people contacted, 15 responded, and 12 were interviewed. The semi-structured interviews were conducted by authors MM and GW. GW developed the list of initial codes based on the questionnaire. MM and GW coded all the interviews and identified nine emergent codes to be added. Following the finalization of the coding criteria, MM re-coded all of the interviews, the tabulation of which can be found in Table 1. The results of the coding were discussed by all authors to develop the set of policy recommendations.

\section{Results}

The following five themes were identified through the interviews and are referenced with the coding in Table 1:

\section{Recognition of the burden of disease}

Burden of disease, including health problems and medical supplies, was a recurrent theme referenced 40 times. The most recurrent healthcare need of refugees in Za'atari was chronic disease management, including emergent needs and long-term complications (Table 2). Refugees with preexisting conditions such as diabetes may arrive to Jordan with serious exacerbations because of lack of access to medications during their travel and in the Syrian Arab Republic. In addition, Za'atari's setting in the open desert with hot summers, dust storms, and cold winters, coupled with a dearth of options for exercise and healthy food, can worsen many chronic conditions.

In contrast, the biggest health issues for refugees arriving in Lampedusa are infectious diseases (Table 2). Even if refugees are otherwise healthy, the unsanitary and low-resource conditions in which they travel increase their susceptibility to communicable diseases. Scabies and bacterial infections are prevalent, as well as skin burns due to exposure to the overseas traveling conditions, including salty water, urine accumulated in the crowded boats, sun exposure, and proximity to the boat motor (9-11).

Reproductive health is a priority, whether in Lampedusa or in Za'atari. One in five households in Za'atari is led by a woman, and the average weekly birth rate in the camp is 80 per 80000 total persons of concern (12). Moreover, refugees often spend three or more years in camp, necessitating comprehensive paediatric and maternal healthcare services. Currently, $100 \%$ of births are attended by skilled medical personnel, and no maternal deaths were reported in 2015. Pregnant refugees arriving in Lampedusa require immediate gynecologic care, although the population's transience makes longterm antenatal and postpartum care difficult to provide. In addition, sexual or gender-based violence has been documented and identified as an important area of concern by the UNHCR, requiring specialized services in both Za'atari and Lampedusa (13).

\section{Health screening and documentation needs}

Screening and treatment for psychiatric disorders is a critical health need in Za'atari and Lampedusa (Table 3). In Za'atari, the International Medical Corps (IMC), a UNHCR-funded NGO, has been tasked with mental health service coordination with the goal of integrating mental health into primary care (14). Currently, refugees entering Jordan are screened for general health conditions at a government-run registration centre in collaboration with NGOs and are then sent to a UNHCR camp for potential follow-up. Some health clinics in Za'atari perform their own screenings, but the presence of an on-site trained mental health provider is not guaranteed. Mental health screening on arrival in Lampedusa is burdensome owing to the sheer number of refugees, making it impossible to screen everyone for psychological disorders $(7,9)$. Most refugees do not stay in the migrant centres for long, so many mental disorders may not be diagnosed. Overall, mental health screening was referred to as being conducted in three instances and was lacking in seven instances.

\section{Mechanisms for improving coordination of care}

While more interviewees referred to coordination of care being effective than lacking, at 19 and eight, respectively, five referred to centralizing coordination in order to 
improve health service delivery. Providing healthcare to refugees in Jordan is logistically more feasible inside the camp than in urban settings because of the centralized framework and geographic proximity (14). Communication between the registration centre and the camp appears to be done on an informal basis (15). The UNHCR, which receives funds from international donors and national governments, is the coordinating arm of Za'atari camp (Table 4). It manages the multifaceted health sector and mediates with the Jordanian government. An extensive list of UNHCR implementing partners is available on its webpage, but no comprehensive compilation of services, facilities, or medications exists for healthcare providers to use in either Za'atari or Lampedusa $(9,16)$. However, the UNHCR recently launched the Inter-Agency Coordination Briefing Kit to facilitate information sharing and improve coordination (17). Furthermore, minutes from UNHCR's bimonthly management and sectorial coordination meetings, including health services in Za'atari, are posted online (18). While areas of need remain, Za'atari camp has been recognized for its coverage of primary and secondary health needs of refugees, as well as outbreak response mechanisms, especially in light of the fluctuating number of refugees, NGO participation, and funding $(14,19)$.

Starting with the influx of refugees in 2010, the Italian government implemented a health information system, including public health surveillance mechanisms to report to the Italian ministry of health $(\mathrm{MoH})(20,21)$. The $\mathrm{MoH}$ has also adapted a WHO toolkit to conduct a series of assessments on the health system impact of the influx of migrants and crisis management (Table 3) (22,23). Upon arrival to Lampedusa, NGOs such as the Red Cross and Doctors Without Borders triage patients with assistance from the $\mathrm{MoH}$, but within the migrant centres that house refugees, the provision of services is the responsibility of the Ministry of the Interior (Table 4) $(9,24)$.

\section{Cultural competency training for healthcare providers}

There were 19 references to cultural competency and 11 references to language concordance in the interviews. Refugee healthcare providers often lack linguistic or cultural concordance with their patients, so training and interpreter services are critical to maintaining high-quality care. Many organizations in Za'atari rely on volunteer healthcare providers who may be unfamiliar with the culture and language, underscoring the need for prior training (Table 3). Similarly, refugees arrive at Lampedusa from dozens of countries with unique languages and practices, increasing the complexity of healthcare provision. In Lampedusa, cultural mediators can help provide culturally competent translation. Medical providers in Za'atari said some of their best interpreters had been residents of the camp because they understood the "culture" of the camp, including additional resources available to patients $(11,12,25)$.

\section{Long-term needs and international response}

Addressing mental health needs, social determinants of health, such as job opportunities, and follow-up care, were referred to 11,12 , and 14 times respectively. Thus, providing healthcare to refugees is not a one-time endeavour but an ongoing commitment by the international community. Components of this international response include not only funding, but also awareness and advocacy initiatives, trained medical providers, and ultimately, a political solution to the conflict.

\section{Discussion and recommendations}

A summary of the following recommendations organized by theme can be found in Table 5 . In both Jordan and Italy, leaders have called for a more coordinated and centralized approach to delivering healthcare to refugees $(7,9,10,16)$. The coordination of healthcare services should be centralized with one entity in all settings and integrated into an overarching model of care. In Italy, the government should lead coordination efforts because it is the main funder of healthcare. In Lampedusa, centralizing control of health services with the Servizio Sanitario Nazionale would improve coordination among the various organizations and allow for more collaboration and input from WHO (11). In Za'atari, services are coordinated by the UNHCR, which is taking concrete steps towards management and dissemination of information among its implementing partners. For example, it has helped develop implementation tools and standard operating procedures, such as a cholera preparedness plan, which has been adopted by the Jordanian $\mathrm{MoH}$ as a national guideline $(14,26)$. This model of multisector meetings and focus groups is also applicable in the context of Lampedusa.

For mental health, screening and treatment should be combined with primary healthcare services rather than the current vertical model. Psychoeducational materials must be made available to refugees in order to raise awareness about mental health conditions and complications, provide basic management techniques, and bolster community support $(16,25)$. Many refugees, especially parents with affected children, are unaware of or confused about symptoms (16). Importantly, a robust infrastructure must be in place for psychotherapeutic treatment to accommodate follow-up for both paediatric and adult patients (27). Better communication can be achieved through providing a list of available follow-up services and resources for psychosocial therapy and would help improve coordination among organizations and assist healthcare providers in making better referrals.

Government engagement is critical in order for the response to be coordinated and integrated within a national system. Regular meetings between the $\mathrm{MoH}$, NGOs, and UNHCR/WHO will promote communication among stakeholders, as well as public dissemination of the results. Even though NGOs often provide basic healthcare, government involvement is necessary for disease surveillance and referrals, especially in Jordan 
where refugees often reside for years. Since a Jordanian government policy change in 2014, only limited financial assistance is available to refugees in non-camp settings seeking care in $\mathrm{MoH}$ facilities (28). More focus should also be directed towards providing care to city-dwelling populations.

\section{Provider training in refugee health}

While many organizations still rely on volunteers, training local healthcare providers will increase cost effectiveness and sustainability. The limited number of health professionals, especially psychiatrists and psychologists, is a major barrier in providing care. Community-based healthcare workers can increase awareness about disease prevention and management, connect refugees to health resources, and improve system efficiency, especially with limited numbers of physicians available $(28,29)$. Programmes to train refugees in this capacity will improve health and contribute to livelihood engagement, especially in the camp settings where long-term care is important.

In addition, more resources for identifying and training high-quality interpreters is important so that language is not the primary barrier for refugees to access care. In Za'atari, Jordanian physicians have higher linguistic, religious, and cultural concordance with Syrian refugees than do many of the physicians who come from other countries. Furthermore, hiring locally can contribute to the local economy. We recommend that refugees be trained as interpreters, especially in camp settings, where such opportunities can lead to local empowerment as well as sustainable delivery.

Training programmes for healthcare providers in refugee healthcare and cultural competency are an underutilized but valuable tool (11). Culturally competent care can improve recognition of medical problems, build trust and relationships, provide context for seemingly unusual behaviours, and improve communication between patient and provider. For example, the American University in Beirut, Lebanon, recently established a Conflict Medicine Programme, and Unite for Sight partnered with Harvard Medical School, United States, to offer a certificate programme for refugee health and trauma $(30,31)$. Other tools including case-based learning, shadowing opportunities, and Internet resources should be used by students and professionals. These programmes should be part of a larger initiative in cultural competency training.

\section{Investment in robust documentation}

Poor documentation is a major barrier to providing care to refugees. Systems for tracking top health issues have been put in place in Za'atari and Lampedusa. Disease surveillance programmes in Jordan have proven to be invaluable for obtaining health-related data and allocating resources (14). Readily available technology, including SMS, should be utilized to provide health-related updates and reporting (14).

The current minimal health record documentation presents major complications with continuity of care, especially since providers are constantly changing. Furthermore, refugees may arrive without any information on prior medical conditions, so the documentation process should start as soon as possible. Especially when handling personal health information, a formal process for communicating and maintaining privacy must be in place. In Za'atari each registered refugee should have an electronic file with the results of the initial health screening, which can be updated and shared with healthcare providers in the camps. Currently, providers write medical information on a WHO paper form given to each refugee, but these can be misplaced easily, and records may be incomplete or inadequate. On the other hand, paper documentation for refugees arriving in Lampedusa is ideal because despite drawbacks, it would allow patients to carry their medical information with them to their final destination.

Organizations must adopt standard operating procedures that require documentation and transparency. Available health services and facilities should be compiled to help physicians make referrals, identify gaps in services, and improve utilization of available resources in the camp. It would also improve integration of temporary volunteers and continuity of care with long-term providers. Similarly, a comprehensive list of medications and medical supplies should be maintained so that the available resources are known and depleted resources identified.

\section{Funding and advocacy}

Funding for health services is overstretched, and resources are limited, so monetary and technical assistance from the international community is critical. UNHCR in Za'atari and the Italian government in Lampedusa must continue to improve coordination to utilize healthcare funding efficiently and to integrate services.

While not directly related to healthcare provision, advocacy is critical for spreading awareness about the support needed for refugees. For example, healthcare providers who return from service missions have a unique opportunity to become advocates for refugees, whether through conferences, interviews, opinion articles, or mentoring other students and colleagues. In addition, local NGO initiatives for refugees that address social determinants of health, such as offering language courses, can also have positive effects on the host communities.

\section{Conclusion}

The health of refugees is of utmost importance not only for their personal well-being and safety but also for the health of host communities. Through our interviews with individuals who have worked in either Za'atari, Jordan or Lampedusa, Italy, we identified themes and created recommendations to further improve healthcare response efforts targeted for refugees. Chronic disease management for camp-based refugees, and infectious disease management for in-transit refugees remain pri- 
orities. Mental health screening and services need consistent standards of care and dedicated provider training, especially in cultural competency. Healthcare-providing organizations can improve their efficacy by both investing in documentation strategies and centralizing their care models. Finally, as many gap remains in local, national, and international funding, public engagement and advocacy for refugees' rights remain critical aspects of an integrated response to providing healthcare for refugees, whether in Jordan, Italy, or around the world.

\section{Acknowledgements}

We would like to express our gratitude to the following individuals for taking time out of their busy schedules to share their experiences and views: Mohammad Abo-Hilal, co-founder, Syria Bright Future; Sara Barragan-Montes, technical officer on public health and migration, WHO/Europe; Gianfraco Costanzo, head international relations, The National Institute for Health Migration and Poverty in Rome, Italy; Asaad Kadhum, public health officer, UNHCR Office in Jordan; Marissa Leslie, medical director, behaviour health and wellness services, Adventist Health Care; Gregory Lewis, clinical psychologist, Alliance Clinical Associates; Alberto Mallardo, analyst and cultural mediator, Mediterranean Hope; Aldo Morrone, director, Mediterranean Institute of Hematology (former director, National Institute of Health, Migration, and Poverty in Rome, Italy); Valeska Padovese, dermato-venereology consultant, Maltese Ministry of Health; Zaher Sahloul, president, Syrian American Medical Society; and Iyad Shytiat, assistant public health officer, UNHCR Za'atari Camp.

Funding: None.

Competing interests: None declared.

\begin{tabular}{|c|c|c|c|c|c|}
\hline \multirow{2}{*}{ Theme } & \multirow{2}{*}{ Code Cluster } & \multicolumn{2}{|c|}{ Preliminary Codes } & \multicolumn{2}{|c|}{ Emergent Codes } \\
\hline & & Category & Count & Category & Count \\
\hline \multirow[t]{5}{*}{1} & \multirow[t]{3}{*}{ Health problems } & Infectious disease & 7 & Burns & 3 \\
\hline & & Chronic conditions & 9 & Hypothermia & 1 \\
\hline & & Mental health & 17 & Maternal health & 3 \\
\hline & \multirow[t]{2}{*}{ Medical supplies } & - & - & Insufficient supplies & 4 \\
\hline & & - & - & Sufficient supplies & 8 \\
\hline \multirow[t]{4}{*}{2} & \multirow[t]{2}{*}{ Health screening } & $\begin{array}{l}\text { Mental health } \\
\text { screening conducted }\end{array}$ & 3 & $\begin{array}{l}\text { General health } \\
\text { screening conducted }\end{array}$ & 8 \\
\hline & & $\begin{array}{l}\text { Mental health } \\
\text { screening lacking }\end{array}$ & 7 & $\begin{array}{l}\text { General health } \\
\text { screening lacking }\end{array}$ & 2 \\
\hline & \multirow[t]{2}{*}{ Documentation } & $\begin{array}{l}\text { Medical records } \\
\text { present }\end{array}$ & 6 & Surveillance & 4 \\
\hline & & $\begin{array}{l}\text { Medical records } \\
\text { lacking }\end{array}$ & 5 & - & - \\
\hline \multirow[t]{6}{*}{3} & \multirow[t]{2}{*}{ Coordination of care } & Effective coordination & 19 & Centralizing control & 5 \\
\hline & & $\begin{array}{l}\text { Ineffective } \\
\text { coordination }\end{array}$ & 8 & - & - \\
\hline & \multirow[t]{2}{*}{ Financing } & $\begin{array}{l}\text { National health } \\
\text { system/MoH }\end{array}$ & 10 & WHO/UN & 18 \\
\hline & & NGOs & 15 & - & - \\
\hline & \multirow[t]{2}{*}{ Resource priorities } & - & - & Access to resources & 26 \\
\hline & & - & - & Discrimination & 7 \\
\hline \multirow[t]{4}{*}{4} & \multirow[t]{2}{*}{ Healthcare providers } & Volunteers & 13 & Training & 23 \\
\hline & & Paid employee/staff & 20 & - & - \\
\hline & \multirow{2}{*}{$\begin{array}{l}\text { Humanistic } \\
\text { competency }\end{array}$} & Cultural competency & 19 & - & - \\
\hline & & Language concordance & 11 & - & - \\
\hline \multirow[t]{4}{*}{5} & \multirow[t]{2}{*}{$\begin{array}{l}\text { Long-term health } \\
\text { needs }\end{array}$} & Mental health & 11 & $\begin{array}{l}\text { Social determinants } \\
\text { of health }\end{array}$ & 12 \\
\hline & & Chronic conditions & 5 & Follow-up care & 14 \\
\hline & \multirow{2}{*}{$\begin{array}{l}\text { International } \\
\text { response }\end{array}$} & \multirow[t]{2}{*}{ Funding } & 6 & Awareness/advocacy & 9 \\
\hline & & & 2 & Political solution & 6 \\
\hline
\end{tabular}

*Preliminary codes were created a priori based on the interview questions; emergent codes were created after coding of the interviews; and then code clusters were formed to form five overarching themes.

$\mathrm{MoH}=$ Ministry of Health; $\mathrm{NGO}=$ Nongovernmental Organization; $\mathrm{UN}=$ United Nations; $W H O=$ World Health Organization 


\begin{tabular}{|c|c|c|}
\hline Theme & Za'atari & Lampedusa \\
\hline \multirow[t]{2}{*}{ Health Needs } & $\begin{array}{l}\text { - Chronic disease management (hypertension, diabetes, asthma) } \\
(6,14,16,19,26) \\
\text { - Healthy lifestyle and food options } \\
\text { - Tertiary care }\end{array}$ & $\begin{array}{l}\text { - Infectious diseases (scabies, } \\
\text { bacterial infections) }(9,20,26) \\
\text { - Hypothermia (11) } \\
\text { - Skin burns }(9,11)\end{array}$ \\
\hline & \multicolumn{2}{|c|}{ - Mental health (depression, anxiety, and posttraumatic stress disorder) $(11,16,19,20,25,26,29)$} \\
\hline Available Health Services & $\begin{array}{l}\text { - Free primary and secondary health care } \\
\text { - Disease surveillance and outbreak response }(7,14,20,26) \\
\text { - Maternity health care }\end{array}$ & $\begin{array}{l}\text { - Variable, although a disease } \\
\text { surveillance system is in place }\end{array}$ \\
\hline Gaps in Health Services & \multicolumn{2}{|c|}{$\begin{array}{l}\text { - Screening and treatment for mental health }(9,14,16,19,29) \\
\text { - Sexual or gender-based violence prevention, reporting system, and treatment } \\
\text { - Tertiary care coverage }\end{array}$} \\
\hline
\end{tabular}

\begin{tabular}{|c|c|c|}
\hline \multirow{2}{*}{ Theme } & \multicolumn{2}{|l|}{ Quote } \\
\hline & Za'atari & Lampedusa \\
\hline $\begin{array}{l}\text { Health Problems: Mental Health \& } \\
\text { Screening }\end{array}$ & $\begin{array}{l}\text { Mental health services in Jordan are vertical, but they need to be part of } \\
\text { primary health care, so a more integrated approach is needed to reduce } \\
\text { the stigma and improve cost-effectiveness. This will be a goal for } 2016 \\
\text { (14). }\end{array}$ & $\begin{array}{l}\text { - Infectious diseases (scabies, } \\
\text { bacterial infections) }(9,20,26) \\
\text { - Hypothermia }(11) \\
\text { - Skin burns }(9,11)\end{array}$ \\
\hline Coordination of Care & $\begin{array}{l}\text { "There are processes that could be streamlined if UNHCR took a more } \\
\text { proactive role on this issue." (19) }\end{array}$ & $\begin{array}{l}\text { "In many countries, this } \\
\text { work is developed in close } \\
\text { collaboration with international } \\
\text { organizations, especially where } \\
\text { UN country teams are present; } \\
\text { and in the specific case of the } \\
\text { MOH, the work is done in close } \\
\text { collaboration with the WHO } \\
\text { Country Office and Regional } \\
\text { Office for Europe." (11) }\end{array}$ \\
\hline Healthcare Providers: Training & \multicolumn{2}{|c|}{$\begin{array}{l}\text { "I also think there could be benefit for people going on missions to have some type of orientation or } \\
\text { training...I think just understanding what it means to work with someone from a different culture, inter- } \\
\text { cultural sensitivity. Trauma, understanding inter-cultural sensitivity, learning how to work with people. } \\
\text { How we often see things through our own eyes...we need to be aware of our own biases and blind spots } \\
\text { before we go learn about your culture." (16) }\end{array}$} \\
\hline $\begin{array}{l}\text { International Response: Advocacy/ } \\
\text { Awareness }\end{array}$ & $\begin{array}{l}\text { "I just want to ensure that our voice reaches all decision-makers to } \\
\text { support and continue supporting refugees in all aspects, including health } \\
\text { services. We are doing our best to serve refugees, but one hand cannot } \\
\text { clap-we need all the help and support we can get. Any donation or any } \\
\text { mission can make the refugee's life better-it can improve their health, } \\
\text { access to health." (26) }\end{array}$ & $\begin{array}{l}\text { "I think that we have to } \\
\text { organize international and } \\
\text { national fundraising for } \\
\text { refugee health services because } \\
\text { if we improve their health } \\
\text { conditions we improve the } \\
\text { health conditions of the Italians } \\
\text { or Europeans too." (7) }\end{array}$ \\
\hline
\end{tabular}

${ }^{*}$ Representative examples of quotes were selected from interviews.

\begin{tabular}{|c|c|c|}
\hline Coordination Mechanisms & Za'atari & Lampedusa \\
\hline Implementing Organization & UNHCR, MoH & Italian government \\
\hline Documentation and Screening & Jordanian government, UNHCR and implementing partners & NGOs, migrant centers (MoI) \\
\hline Surveillance & UNHCR implementing partners & WHO, Italian government \\
\hline Standard Operating Procedures & WHO, UNHCR, Jordanian government & $\begin{array}{l}\text { National Institute of Health, } \\
\text { Migration, and Poverty; WHO/ } \\
\text { Europe }\end{array}$ \\
\hline Meeting of Stakeholders & UNHCR and partners & $\begin{array}{l}\text { WHO and European } \\
\text { government leaders }\end{array}$ \\
\hline
\end{tabular}

${ }^{*}$ Differing structures of healthcare delivery options for refugees exist in Za'atari vs. in Lampedusa.

$\mathrm{MoH}=$ Ministry of Health; $\mathrm{MoI}=$ Ministry of Interior; $\mathrm{NGO}=$ Non-governmental Organization; $\mathrm{UNHCR}=$ United Nations High Commissioner for Refugees; WHO = World Health Organization 


\begin{tabular}{|c|c|}
\hline $\begin{array}{l}\text { Coordination } \\
\text { Mechanisms }\end{array}$ & Za'atari \\
\hline $\begin{array}{l}\text { Coordinated Response } \\
\text { Efforts }\end{array}$ & $\begin{array}{l}\text { Improve communication and } \\
\text { collaboration between various } \\
\text { stakeholders and centralize response } \\
\text { effort within one organization or agency, } \\
\text { and integrate mental healthcare into } \\
\text { existing primary care infrastructure }\end{array}$ \\
\hline $\begin{array}{l}\text { Improved Training for } \\
\text { Providers }\end{array}$ & $\begin{array}{l}\text { Teach healthcare professionals to provide } \\
\text { culturally-competent care, and provide } \\
\text { opportunities for refugees to serve as } \\
\text { interpreters }\end{array}$ \\
\hline $\begin{array}{l}\text { Robust Documentation } \\
\text { Mechanisms }\end{array}$ & $\begin{array}{l}\text { Improve documentation, both for } \\
\text { individual patients to improve medical } \\
\text { record keeping, and of existing resources } \\
\text { to improve communication }\end{array}$ \\
\hline Funding and Advocacy & $\begin{array}{l}\text { Raise awareness about the magnitude of } \\
\text { the current refugee crisis and the gap in } \\
\text { funding and resources currently available }\end{array}$ \\
\hline
\end{tabular}

\section{Supplement 1. Semi-structured inter- view questions.}

Interview questions were created based on a literature review and were sent to interviewees prior to the interview.

\section{Background of interviewee}

1. How have you been involved over the past few years with healthcare for refugees?

\section{Health issues and services}

2. In your opinion, what are the top three health issues among refugees/migrants?

3. What materials and products are the most important for health maintenance for refugees and migrants?

a. Who is paying for/providing these?

b. Are there enough of these materials?

4. What health issues are refugees screened for upon arrival?

a. Follow up: Are all or most refugees screened for mental health? Can you explain the process

5 . What follow-up is there to the screening results, and how are records kept (e.g., electronically)? a. How do patients with chronic conditions receive and pay for their medication?

b. How are immunizations tracked?

6. Who are the main health care providers (nationality, training, volunteer vs. paid)?

a. What type of health care workers and services are most needed at this time and for the near future?

7. How are healthcare provision efforts coordinated between different organizations (government, non-pro it, etc.)

a. How do you think coordination can be improved?

8. What have been the greatest successes in health care provision that you have witnessed so far?

a. Are there particular models that have worked well?

9. As international funding decreases, where do you think resources for refugee health services should be prioritized?

\section{Training}

10. What sort of humanistic competency training do "health care providers" receive, such as linguistic, cultural, or religious competency?

a. Who provides these trainings?

b. What aspects are most lacking?

11. In what specific ways can training for staff members and healthcare providers be improved to meet the needs of refugees?

12. How have security issues (within the camps) affected the health of the refugees?

a. How are security issues addressed (e.g., programs, education initiatives, trainings)?

\section{Resettlement}

13. How long do most refugees actually stay in the migrant centers/camps?

a. Where do most refugees go after they leave the camps?

14. As refugees resettle in other communities across the world, what do you expect their most pressing healthcare needs to be?

15. What can the international community do to help most? 


\section{Besoins de santé des réfugiés au port d'arrivée par rapport aux camps permanents Résumé}

Contexte : La population mondiale de réfugiés a dépassé les 21 millions, dont la grande majorité se trouve dans des pays en développement. Les réfugiés ont des taux relativement élevés de recours aux soins de santé pour la prise en charge des besoins à long terme, tels le diabète, et des maladies aiguës, telles que la gale.

Objectifs : Par le biais d'entrevues avec des intervenants dans des milieux de soins de santé différents, notre objectif était de déterminer les thématiques communes ainsi que les domaines montrant des différences qui devraient être identifiés et pris en compte au fur et à mesure que la crise des réfugiés se poursuit.

Méthodes : La présente étude qualitative par entretiens compare et met en contraste deux contextes de prestation de soins de santé aux réfugiés : le camp permanent de Za'atari, en Jordanie, et le point d'arrivée transitoire de Lampedusa en Italie.

Résultats : Nous présentons les données de 12 entrevues semi-structurées avec des experts en soins de santé aux réfugiés ayant de l'expérience avec ces deux types d'emplacements. Nous nous sommes concentrés sur les questions de la charge de morbidité et du dépistage des maladies, des structures et des services organisationnels, des compétences culturelles et des interventions internationales.

Conclusions : Nous avons compilé des recommandations pour améliorer les soins de santé aux réfugiés, y compris la reconnaissance des différents besoins de santé des réfugiés à Za'atari et Lampedusa, la formation de prestataires de soins culturellement compétents, le dépistage et la prise en charge des troubles psychiatriques et l'établissement de priorités en matière de coordination, de documentation et de plaidoyer.

$$
\text { الاحونياجات الصاتسو موتو، للاجئين: مقارنة بين ميناء الوصول والمخييل وايمر، عائشة سيثيات الدائمة }
$$

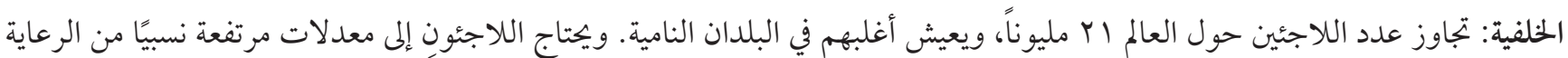

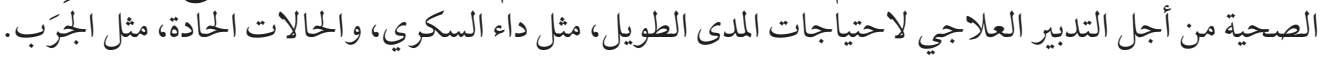

الأهداف: من خلال المقابلات مع أصحاب المصلحة في مختلف مرافت الرعاية الصحية، هدفنا إلى تفسير الموضوعات الشائعة وبجالات الاختلاف

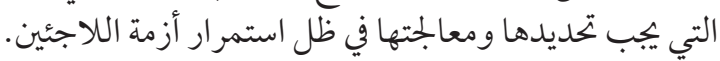

طرق البحث: تقارن دراسة المقابلة النوعية هذه بين مرفقين للرعاية الصحية المقدمة للاجئين: المرفق الدائم لمخيم الزعتري في الأردن، مقابل مكان الوصول الانتقالي لامبيدوزا في إيطاليا.

النتائج: نقدم بيانات من ب ا مقابلة شبه مهيكلة مع الخبراء في الرعاية الصحية للاجئين الذين لديهم خبرة في هذه المكانين. ونركز على مشكلات عبء المرض، والفحص الصحي، والهياكل والخدمات التنظيمية، و الكفاءة الثقافية، والاستجابة الديه الدولية.

الاستنتاجات: جمعنا توصيات بهدف تحسين الرعاية الصحية المقدمة للاجئين، بما في ذلك تحديد الاحتياجات الصحية المختلفة للاجئين في خخيم

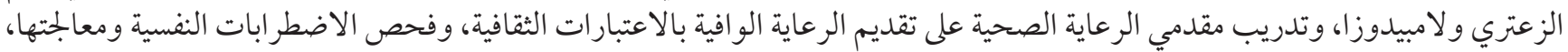

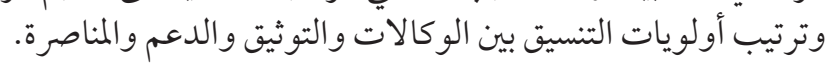

\section{References}

1. United Nations High Commissioner for Refugees. Figures at a Glance. Geneva: UNHCR; 2015. (http://www.unhcr.org/figures-ata-glance.html, accessed 7 May, 2017).

2. United Nations High Commissioner for Refugees. Refugees/Migrants Emergency Response Mediterranean Regional Overview. Geneva: UNHCR; 2016. (http://data2.unhcr.org/en/situations/mediterranean).

3. International Organization for Migration. Europe/Mediterranean: mixed flows in the Mediterranean and beyond; flows compilation overview 2015. Geneva: IOM; 2016. (https://www.iom.int/sitreps/europemediterranean-mixed-flows-mediterranean-and-beyond-flows-compilation-overview-2015).

4. WHO Regional Office for Europe. Sicily, Italy: Assessing health-system capacity to manage sudden large influxes of migrants. Joint Report on a Mission of the Regional Health Authority of Sicily. Copenhagen: EURO; 2015. (http://www.euro.who.int/en/ publications/abstracts/sicily,-italy-assessing-health-system-capacity-to-manage-sudden-large-influxes-of-migrants2).

5. United Nations High Commissioner for Refugees. Camp ZR. Geneva: UNHCR; 2017. (http://data.unhcr.org/syrianrefugees/settlement.php?id=176\&region=77\&country=107). 
6. World Health Organization. From the migration front line: interview with Lampedusa doctor. Geneva: World Health Organization; 2015. (http://www.euro.who.int/en/health-topics/health-determinants/migration-and-health/news/news/2015/04/from-themigration-front-line-interview-with-lampedusa-doctor).

7. Aldo Morrone, interview by Gabrielle Wimer, Februrary 17, 2016, trascript.

8. United Nations High Commissioner for Refugees. Zaatari Refugee Camp. Geneva: UNHCR; 2017. (http://data.unhcr.org/syrianrefugees/settlement.php?id=176\&region=77\&country=107).

9. Valeska Padovese, interview by Gabrielle Wimer, February 3, 2016, transcript.

10. Alberto Mallardo, interview by Gabrielle Wimer, March 26, 2016, transcript.

11. Sara Barragan Montes (WHO/Europe), interview by Gabrielle Wimer, March 17, 2016, transcript.

12. United Nations High Commissioner for Refugees. Camp ZR. “Geneva: UNHCR; 2017. (http://data.unhcr.org/syrianrefugees/settlement.php?id=176\&region=77\&country=107).

13. United Nations High Commissioner for Refugees. Sexual and Gender-Based Violence: Syrian Refugees in Jordan. Sexual and Gender-Based Violence Sub Working Group. Geneva: UNHCR; 2014 (http://data.unhcr.org/syrianrefugees/download. php?id=5165)

14. Asaad Kadhum (UNHCR), interview by Monica Matsumoto, February 25, 2016, transcript.

15. Anonymous. Refugee health in Za'atari. 2016; Online interview, Feb. 2016.

16. Gregory Lewis, interview by Monica Matsumoto, February 25, 2016, transcript.

17. United Nations High Commissioner for Refugees. Jordan Refugee Response: Inter-agency coordination briefing kit. Geneva: UNHCR; 2017. (http://data.unhcr.org/syrianrefugees/download.php?id=11118).

18. United Nations Development Programme. Updated overview: 2015 Syria Response Plan and 2015-2016 Regional Refugee and Resilience Plan. New York: UNDP; 2015. (http://www.undp.org/content/dam/rbas/doc/SyriaResponse/Kuwait III/Overview of 2015 Response Plans for Syria Crisis.pdf).

19. Zaher Sahloul, interview by Monica Matsumoto, January 21, 2016, transcript.

20. Gianfranco Costanzo, interview by Gabrielle Wimer, March 9, 2016, transcript.

21. Napoli C, Riccardo F, Declich S, Dente MG, Pompa MG, Rizzo C, et al.; The National Working Group. An early warning system based on syndromic surveillance to detect potential health emergencies among migrants: results of a two-year experience in Italy. Int J Environ Res Public Health. 2014;11(8):8529-41. http://dx.doi.org/10.3390/ijerph110808529

22. Francesco B, Santino Severoni M, Barragan Montes S. Promoting Intersectoral Public Health Responses to Large-Scale Migration: The Example of Sicily, Italy. Public Heal Panor. 2015;1:56-61.

23. World Health Organization.Toolkit for assessing health-system capacity to manage large influxes of refugees, asylum seekers and migrants in the initial phase. Geneva: World Health Organization; 2012. (http://www.who.int/mental_health/resources/ toolkit_mh_emergencies/en/).

24. International Federation of Red Cross and Red Crescent Societies. Revised emergency appeal, Italy: population movement. Geneva: International Federation of Red Cross and Red Crescent Societies; 2015 (http://adore.ifrc.org/Download.aspx?FileId=108656).

25. Marissa Leslie M, interview by Monica Matsumoto, February 23, 2016, transcript.

26. Iyad Shytiat (UNHCR), interview by Monica Matsumoto, February 3, 2016, transcript.

27. Ventevogel P, Schinina G, Strang A, Gagliato M, Hansen LJ. Mental health and psychosocial support for refugees, asylum Seekers and migrants on the move in Europe. A multi-agency guidance note." Geneva: World Health Organization; 2015. (http://www. euro.who.int/en/health-topics/health-determinants/migration-and-health/publications/2016/mental-health-and-psychosocialsupport-for-refugees,-asylum-seekers-and-migrants-on-the-move-in-europe-a-multi-agency-guidance-note-2015).

28. 3RP Regional Refugee \& Resilience Plan 2016-2017. (http://www.3rpsyriacrisis.org/, accessed July 13, 2016).

29. Mohammad Abo-Hilal (Syria BF), interview by Monica Matsumoto, February 28, 2016, transcript.

30. AUB announces the establishment of a "Conflict Medicine Program" as part of Strategic Health Initiatives (SHI).Beirut: American University in Beirut; 2016. (https://www.aub.edu.lb/communications/media/Documents/may-16/cmp-EN.pdf

31. Certificate in Refugee Health. Unite for Sight. 2015 (http://www.uniteforsight.org/global-health-university/refugee-health-certificate). 